\title{
Itsekkyys valtaa alaa aikuiskasvatuksessa
}

Aikuiskasvatuksen valtakunnallista suunnittelua on harjoitettu Suomessa jo lähes kaksikymmentä vuotta. Aikuiskoulutuskomitean I osamietinnöstä lähtien on korostettu sitä, että aikuiskasvatuksen yhtenä perustavoitteena on edistää sivistyksellistä tasa-arvoisuutta, eli vähentää koulutuksellista eriarvoisuutta. Tämä tavoite kirjattiin myös vuonna 1978 annettuun "Aikuiskasvatuksen periaatepäätökseen". Tuolloin kaikki yhteiskunnan eri intressiryhmät olivat yksimielisesti tavoitteen takana. En ainakaan muista, että kukaan olisi tuolloin julkisesti vastustanut sitä. Tasa-arvotavoitteen konkretisointi on kuitenkin jäänyt meillä tekemättä ja näyttää siltä, ettei tähän tavoitteeseen enää kovin ponnekkaasti edes pyritä. Työelämän eri intressiryhmätkin ajavat tänä päivänä entistä itsekkäämmin vain omia etujaan välittämättä huonompiosaisista ja vähemmän koulutetuista. Tämä kävi ilmi mm. palkansaajajärjestöjen aikuiskoulutusseminaarissa, joka pidettiin elokuussa Siikaranta-opistossa. Kaikki palkansaajajärjestöt eivät ole enää yhtä innokkaasti ajamassa koulutuspalvelusten tasa-arvoistamista kuin aikaisemmin. Se, etteivät työnantajat pyri tähän tavoitteeseen omassa henkilöstökoulutuksessaan, ei liene kellekkään mikään uutinen.

Intressien eriytyminen on tiettyyn rajaan asti luonnollista ja ymmärrettävää, mutta jos siinä mennään kovin pitkälle, niin se vaikeuttaa aikuiskasvatusjärjestelmämme kokonaisvaltaista kehittämistä. Tällä hetkellä on nähtävissä kaksi erilaisiin intresseihin perustuvaa rintamajakoa: toisaalta palkansaajat ja työnantajat sekä toisaalta eri palkansaajaryhmät, joilla on hiukan toisistaan poikkeavia painotuksia - johtuen jäsenkunnan aikaisemmasta koulutuksesta ja asemasta työelämän hierarkiassa - koulutuspoliittisessa tavoitteenasettelussaan.

Palkansaajien ja työnantajien intressiristiriidat näkyvät siten, että kaikki palkansaajien keskusjärjestöt vaativat työnantajia tehostamaan henkilöstökoulutustaan, jopa kaksinkertaistamaan sen. Vaatimus on varsin ymmärrettävä erityisesti niiden keskusjärjestöjen osalta, joiden jäsenkunta on päässyt tällaisesta koulutuksesta osalliseksi vain hyvin vähäisessä määrin. Näin on tilanne erityisesti SAK:n ja TVK:n jäsenkunnan kohdalla. Lääkkeenä henkilöstökoulutuksen resurssiongelmiin palkansaajajärjestöt tarjoavat koulutusrahastoja. Työnantajien mielestä lääke on kuitenkin väärä ja pahanmakuinen. Vaikka työnantajat ovat yhtä mieltä lisäkoulutuksen merkityksestä, niin he eivät ole halukkaita järjestämään sitä itse, koska se aiheuttaa heille lisäkustannuksia. Tästä syystä he pyrkivät siirtämään koulutusvastuun mahdollisimman suurelta osin valtiovallalle ja palkansaajille itselleen. Tässä he ovat onnistuneetkin melko hyvin. 
Palkansaajien keskinäiset intressiristiriidat näkyivät selvimmin STTK:n ja Akavan puheenjohtajien kannanotoissa. He korostivat, ettei näiden suhteellisen hyvin koulutettujen ja työnantajan koulutukseen runsaasti osallistuvien henkilöstöryhmien koulutusta saa missään nimessä vähentää, vaan paremminkin sitä tulee lisätä entisestään. Perusteluina he esittivät, että näillä ryhmillä on muita suurempi koulutustarve ja se, että näihin henkilöihin on yhteiskunnan (ja työnantajan) toimesta sijoitettu jo runsaasti, joten heihin pitää sijoittaa tulevaisuudessakin muita enemmän. Molemmat korostivat, että koulutus on tärkeä keino ajatellen henkilöstön irtișanomissuojaa ja työn pysyvyyttä. Tällöin voidaan kysyä, eivätkö he halua edistää muiden kuin oman jäsenistönsä irtisanomissuojaa. Voidaan nimittäin perustellusti väittää, että suoritustasolla olevien koulutustarpeet ovat tällä hetkellä suuremmat kuin teknisten ja ylempien toimihenkilöiden, koska heidän työpaikkansa säilyminen on selvimmin uhattuna, jos heille ei järjestetä ajoissa koulutusta. En voi hyväksyä ajatusta, että koulutusta tulisi järjestää ensisijaisesti niille, joiden koulutukseen on jo aikaisemminkin sijoitettu eniten yhteiskunnan ja työnantajien varoja.

Palkansaajien koulutuksellista asemaa ei tule tietystikään parantaa siten, että varat otetaan joltakin muulta palkansaajaryhmältä. Näin ei saa tapahtua, koska koulutus on vielä kaikkien ryhmien kohdalla riittämätöntä. On kuitenkin selkeästi tiedostettava, että kun varoja työelämän koulutuksen kehittämiseen jostakin toivottavasti löytyy, niin niistä suurin osa tulee suunnata sellaisille ryhmille, joiden asema työmarkkinoilla on kaikkein uhatuin ja joiden koulutuksessa on selvimmin tällä hetkellä puutteita. Myös työnantajien tulisi tuntea enemmän työntekijöistään vastuuta, eikä siirtää sitä yhteiskunnan harteille, jolloin maksumiehinä toimivat ensisijaisesti palkansaajat itse.

Lyhyen koulutuksen saaneiden problematiikkaan meillä ei ole toistaiseksi kiinnitetty juuri mitään huomiota. On turha kuvitella, että toteutetut yleiset uudistukset sellaisenaan parantavat näiden ryhmien asemaa. Heidän kohdallaan tarvitaan erityistoimenpiteitä. Monissa muissa maissa lyhyen koulutuksen saaneet on otettu aikuiskoulutuspolitiikassa keskeisen huomion kohteeksi ja heidän erityisongelmiensa selvittämiseksi on tehty lukuisia tutkimuksia ja käynnistetty kehittämisprojekteja. Ruotsi tarjoaa tässä suhteessa hyvän esimerkin. Meillä on toteutettu vain muutamia vaatimattomia lyhyen koulutuksen saaneisiin kohdistuvia tutkimus- ja kehittämishankkeita, joilla ei ole ollut mitään laajempaa merkitystä. Tästä syystä olisikin korkea aika ryhtyä tutkimaan heidän erityisongelmiaan sekä käynnistää heidän aktivoimisekseen tarkoitettuja valtakunnallisia opintoja kehittämisprojekteja.

\section{Jukka Tuomisto}

Ps. Aikuiskasvatus -lehden toimitussihteeri on vaihtunut. Pentti Yrjölän siirryttyä kesällä kouluhallituksen vapaan sivistystyön osaston ylitarkastajaksi hoiti toimitussihteerin tehtäviä väliaikaisesti Marja Haapio. Kansanvalistusseuran hallitus valitsi elokuussa uudeksi pedagogiseksi johtajaksi fil.kand. Marja-Liisa Putkosen, joka vakiintuneen käytännön mukaisesti hoitaa samalla myös Aikuiskasvatus -lehden toimitussihteerin tehtäviä. Toivotan lehden toimituskunnan puolesta uuden toimitussihteerin tervetulleeksi. Samalla kiitän lämpimästi Pentti Yrjölää, joka toimi lehden perustamisesta lähtien viime kesään saakka innokkaasti ja tarmokkaasti sen toimitussihteerinä. 